\title{
PENGARUH PROSEDUR REVIU, KOMPETENSI DAN JANGKA WAKTU PELAKSANAAN TERHADAP KUALITAS REVIU LAPORAN KEUANGAN PEMERINTAH DAERAH PADA INSPEKTORAT SE-PROVINSI GORONTALO
}

\author{
ANITA EDA ${ }^{1)}$ HERMAN KARAMOY $^{2)}$ HENDRIK GAMALIEL $^{3)}$ \\ Program Studi Magister Akuntansi Fakultas Ekonomi dan Bisnis Universitas Sam Ratulangi \\ E-mail: anitaeda@yahoo.co.id
}

\begin{abstract}
This study aims to test the influence of the procedure of the review, the competence of the human resources and the implementation period on the quality of the review of the Financial Statements of the Local Government (LKPD) reported to the Inspectorate in the Province of Gorontalo. The data used in this study are primary data which were collected by using questionnaires as the research instrument and then processed by using SPSS. The data were collected from 92 respondents who are the reviewers and have reviewed the Financial Statements of the Local Government. The method used for this research was quantitative with multiple linear regression analysis. The F-test and t-test were used to test the hypothesis simultaneously and partially. The results show that the variables namely the procedure of the review, the competence of the reviewers and the implementation period altogether affect the quality of the review of the Financial Statements of the Local Government. On the other hand, the procedure of the review in partial has no positive and significant influence on the quality of the review. Thus, it can be concluded that the higher understanding of the procedure of the review, the better quality of the review of the Financial Statements of the Local Government. Then, the competence of the human resources has positive and significant influence on the quality of the review as the higher competence of the human resources of the Inspectorate in the Province of Gorontalo, the better quality of the review of the Financial Statements of the Local Governments. In addition, the implementation period has positive and significant effect on the quality of the review since the better quality of the Financial Statement of the Local Government results from the more effective time and budget allocated for the implementation period done by the staff of the inspectorate in the local government.
\end{abstract}

Keywords : The Procedure of the Review, Competence, Implementation Period, the Quality of the Review.

Abstrak. Penelitian ini bertujuan untuk menguji pengaruh prosedur reviu, kompetensi, dan jangka waktu pelaksanaan terhadap kualitas reviu Laporan Keuangan Pemerintah Daerah pada Inspektorat se Provinsi Gorontalo. Data yang digunakan untuk penelitian ini merupakan data primer yang dikumpulkan menggunakan kuesioner sebagai instrumen penelitian dan diolah dengan program SPSS. Data dikumpulkan dari 92 responden yang merupakan aparat pengawas dan yang pernah melakukan reviu Laporan Keuangan Pemerintah Daerah. Metode yang digunakan yaitu kuantitatif dengan analisis regresi linear berganda. Untuk menguji hipotesis secara simultan dan parsial digunakan Uji F dan Uji t. Hasil penelitian menunjukkan bahwa secara simultan variabel prosedur reviu, kompetensi dan jangka waktu pelaksanaan berpengaruh terhadap kualitas reviu Laporan Keuangan Pemerintah Daerah, namun secara parsial, prosedur reviu tidak berpengaruh positif dan signifikan terhadap kualitas reviu Laporan Keuangan Pemerintah Daerah, sehingga dapat disimpulkan bahwa jika pemahaman aparat pengawas terhadap prosedur reviu Laporan Keuangan Pemerintah Daerah lebih maksimal maka kualitas reviu Laporan Keuangan Pemerintah Daerah lebih baik pula. Kompetensi berpengaruh positif dan signifikan, maka semakin tinggi kompetensi sumber daya aparat pengawas yang ada di Inspektorat se Provinsi Gorontalo maka kualitas reviu Laporan Keuangan Pemerintah Daerah akan semakin baik, jangka waktu pelaksanaan berpengaruh positif dan signifikan maka semakin efektif jumlah dan anggaran waktu yang diberikan maka pelaksanaan reviu yang dilakukan oleh aparat pengawas di Inpektorat Daerah akan semakin maksimal, sehingga kualitas reviu Laporan Keuangan Pemerintah Daerah yang dihasilkan akan semakin baik pula. 
Kata Kunci : Prosedur Reviu, Kompetensi, Jangka Waktu Pelaksanaan terhadap Kualitas Reviu.

\section{Pendahuluan}

Pencanangan reformasi manajemen keuangan negara, baik pada pemerintah pusat maupun pemerintah daerah bertujuan untuk menciptakan tata kelola pemerintahan yang baik, salah satu bentuk wujud dari sistem tata kelola pemerintahan yang baik adalah menghasilkan pelaporan yang transparan dan akuntabel. Salah satu bentuk pertanggungjawaban daerah diatur dalam Undang-undang Nomor 17 Tahun 2003 tentang Keuangan Negara, Undang-undang Nomor 32 Tahun 2004 tentang Pemerintahan Daerah bahwa Gubernur/Bupati/Walikota wajib menyampaikan laporan keuangan kepada Dewan Perwakilan Rakyat Daerah (DPRD) dan masyarakat umum setelah diaudit oleh Badan Pemeriksa Keuangan (BPK).

Inspektorat daerah adalah aparat pengawas yang mempunyai tugas melakukan pembinaan dan pengawasan dalam pengelolaan keuangan daerah. Terkait dengan tugasnya selain pengawasan, juga melakukan reviu atas Laporan Keuangan Pemerintah Daerah. Hasil reviu Laporan Keuangan Pemerintah Daerah dinyatakan dalam bentuk Pernyataan Telah Direviu (PTD). Pernyataan ini sebagai dasar pertimbangan pihak ekternal BPK untuk melakukan audit keuangan. Reviu tidak memberikan dasar untuk menyatakan pendapat. Hal ini dikarenakan reviu tidak mencakup suatu pengujian atas kebenaran substansi dokumen melainkan kesesuaian terhadap penggunaan standar akuntansi sebagaimana yang telah diatur dalam Peraturan Pemerintah Nomor 71 Tahun 2010 tentang Standar Akuntansi Pemerintahan sebagai pengganti Peraturan Pemerintah Nomor 24 Tahun 2005 tentang Standar Akuntansi Pemerintahan (SAP).

Fenomena reviu yang terjadi di lapangan masih jauh dari standar reviu sebagaimana tertuang dalam peraturan perundang-undangan yang berlaku. Sehingga secara pragmatis dapat dikatakan Laporan Hasil Reviu (LHR) masih jauh dari kualitas yang diharapkan. Baik tidaknya kualitas reviu tergambar dari ada tidaknya koreksi yang dilakukan oleh Badan Pemeriksa Keuangan (BPK) terhadap angka-angka yang tertuang dalam laporan keuangan hasil reviu. Hal ini disebabkan faktor-faktor antara lain: kurangnya kompetensi sumber daya manusia dalam hal ini aparat pengawas di Inspektorat daerah terhadap prinsip-prinsip akuntansi yang diterapkan dalam penyusunan dan penyajian laporan keuangan, adanya prosedur pelaksanaan yang tidak memenuhi pedoman dan standar reviu, serta waktu pelaksanaan reviu yang sangat singkat.

Kompetensi yang kurang memadai, disebabkan latar belakang pendidikan yang tidak mendukung juga keahlian aparat pengawasan yang melakukan reviu yang belum mengikuti pendidikan substantif reviu. Jangka waktu pelaksanaan yang tidak sesuai dengan waktu yang dibutuhkan dikarenakan anggaran yang tidak tersedia, kelemahan dalam pedoman pelaksanaan yang tidak sesuai dengan prosedur pelaksanaan disebabkan juga oleh masalah pemenuhan dan pengembangan sumber daya manusia. Prosedur reviu yang dilakukan seringkali belum sepenuhnya mengikuti pada Program Kerja Reviu (PKR), bahkan untuk menemukan bukti fisik atas Program Kerja Reviu (PKR) dan Kertas Kerja Reviu (KKR) sulit untuk didapatkan.

Menurut Tandiontong (2016:76), menyatakan bahwa salah satu kreativitas dalam kegiatan auditing, yang termasuk dalam sintesis adalah reviu yang memadai atas struktur pengendalian intern dalam rangka perencanaan audit dan menentukan sifat, saat dan lingkup pengujian yang akan dilakukan. Tuntutan menghasilkan hasil reviu yang berkualitas merupakan tantangan bagi aparat pengawas yang melakukan reviu. Reviu atas Laporan Keuangan Pemerintah Daerah oleh Inspektorat memiliki peran penting dalam membantu 
mewujudkan pemerintah yang bersih, transparan dan akuntabel. Pelaksanaan reviu diharapkan menjadi peringatan dini (early warning system) yang mampu mengurangi temuan hasil pemeriksaan oleh pihak eksternal dalam hal ini Badan Pemeriksa Keuangan (BPK).

Berdasarkan model penelitian menunjukkan hubungan antara variabel independen atau variabel bebas yaitu prosedur reviu, kompetensi dan jangka waktu pelaksanaan terhadap variabel dependen atau variabel terikat yaitu kualitas reviu Laporan Keuangan Pemerintah Daerah. Prosedur reviu dalam pelaksanaan reviu adalah mekanisme atau tahaptahap kegiatan yang digunakan pereviu dalam melakukan reviu yang terdiri dari perencanaan, pelaksanaan dan pelaporan sesuai dengan peraturan perundang-undangan sehingga menghasilkan hasil reviu yang berkualitas.

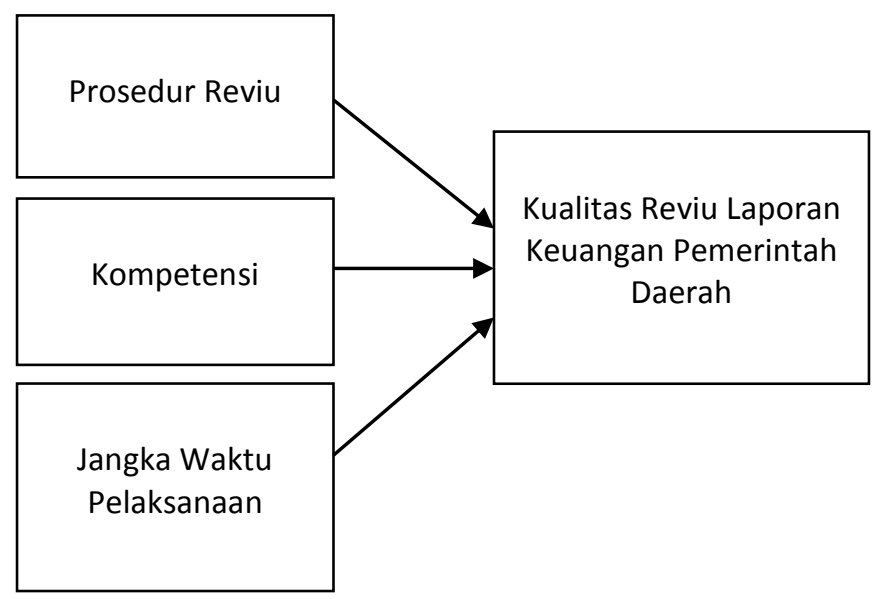

Gambar 1. Kerangka Pemikiran

Menurut Kuntadi (2008), dalam melakukan reviu atas laporan keuangan, aparat pengawasan intern harus memahami secara garis besar sifat transaksi entitas, sistem dan prosedur akuntansi, bentuk catatan akuntansi dan basis akuntansi yang digunakan untuk menyajikan laporan keuangan. Menurut Nugraha (2010), reviu adalah prosedur penelusuran angka-angka, permintaan keterangan dan analitis yang harus menjadi dasar memadai bagi inspektorat untuk memberi keyakinan terbatas atas laporan keuangan bahwa tidak ada modifikasi material yang harus dilakukan atas laporan keuangan agar laporan keuangan tersebut disajikan berdasarkan Sistem Pengendalian Intern (SPI) yang memadai dan sesuai dengan Standar Akuntansi Pemerintahan (SAP).

Menurut Tandiontong (2016:76), menyatakan bahwa salah satu kreativitas dalam kegiatan auditing, yang termasuk dalam sintesis adalah reviu yang memadai atas struktur pengendalian intern dalam rangka perencanaan audit dan menentukan sifat, saat dan lingkup pengujian yang akan dilakukan. Halim dan Budisantoso (2014:286), pelaksanaan prosedur pengajuan pertanyaan dan analisis yang menghasilkan dasar yang memadai bagi akuntan untuk memberikan keyakinan terbatas, bahwa tidak terdapat modifikasi material yang harus dilakukan atas laporan keuangan agar laporan tersebut sesuai dengan basis akuntansi komprehensif yang lain. Berdasarkan Permendagri Nomor 4 Tahun 2008 yang menyatakan bahwa prosedur analitis dirancang untuk mengidentifikasi adanya hubungan antar akun dan kejadian yang tidak biasa serta tidak sesuai dengan SAP.

Menurut Arens et al. (2014:9), reviu atas laporan keuangan historis, manajemen menegaskan bahwa laporan tersebut telah dinyatakan secara wajar sesuai dengan standar akuntansi, sama seperti audit. Akuntan publik hanya memberikan tingkat kepastian yang moderat atau sedang untuk reviu atas laporan keuangan jika dibandingkan dengan tingkat 
kepastian yang tinggi untuk audit, sehingga lebih sedikit bukti yang diperlukan. Menurut Hery (2016:114), langkah-langkah atau prosedur dalam melakukan analisis laporan keuangan adalah:

1. Mengumpulkan data keuangan oleh data pendukung yang diperlukan selengkap mungkin, baik untuk satu periode maupun beberapa periode;

2. Melakukan pengukuran-pengukuran atau perhitungan-perhitungan secara cermat dengan memasukkan angka-angka yang ada dalam laporan keuangan kedalam rumusrumus tertentu;

3. Memberikan interpretasi terhadap terhadap hasil perhitungan dan pengukuran yang telah dilakukan;

4. Membuat laporan hasil analisis;

5. Memberikan rekomendasi sehubungan dengan hasil analisis yang telah dilakukan.

Edison et al .(2016:142), kompetensi adalah kemampuan individu untuk melaksanakan suatu pekerjaan dengan benar dan memiliki keunggulan yang didasarkan pada hal-hal yang menyangkut pengetahuan (knowledge), keahlian (skill), dan sikap (attitude). Sedangkan menurut Spencer dan Spencer (1993) dalam Edison et al. (2016:142), "an underlying characteristic of an individual that is causally related to criterion-referenced effective a/or superior performance ini a job or situation." Kompetensi berhubungan dengan keahlian, pengetahuan, dan pengalaman sehingga auditor yang kompeten adalah auditor yang memiliki pengetahuan, pelatihan, keterampilan, dan pengalaman yang memadai agar bisa menyelesaikan pekerjaannya auditnya (Tandiontong, 2016:172). Fahmi (2015:52), kompetensi adalah suatu kemampuan yang dimiliki seorang individu yang memiliki nilai jual dan itu teraplikasi dari hasil kreativitas serta inovasi yang dihasilkan. Undang-undang Republik Indonesia Nomor 13 Tahun 2003 tentang Ketenagakerjaan pasal 1 ayat 10 menyatakan bahwa kompetensi kerja adalah kemampuan kerja setiap individu yang mencakup aspek pengetahuan, keterampilan dan sikap kerja yang sesuai dengan standar yang ditetapkan. Pasal 11 berbunyi "setiap tenaga kerja berhak untuk memperoleh dan/atau meningkatkan dan/atau mengembangkan kompetensi kerja sesuai dengan bakat, minat, dan kemampuannya melalui pelatihan kerja"

Hal ini juga didukung dengan survey Coram et al. (2003) dalam Tandiontong (2015:202), terhadap staf auditor yang bekerja pada KAP Big 5 dan KAP Non Big 5 dan menemukan kenyataan bahwa staf auditor mengalami tekanan yang dilakukan oleh anggaran waktu audit yang sangat ketat. Tandiontong (2015:201), menyatakan bahwa anggaran waktu (time budget) adalah lamanya waktu yang tersedia yang akan digunakan untuk mengalokasikan waktu yang dibutuhkan setiap tahap pelaksanaan program audit. De Zoort and Lord (1997) dalam Tandiontong (2015:201), menyatakan bahwa ketika menghadapi time budget pressure, auditor akan memberikan respon dengan dua cara yaitu fungsional dan disfungsional

De Angelo (1981) dalam Tandiontong (2015:240), mendefinisikan kualitas audit sebagai kemungkinan bahwa auditor akan menemukan dan melaporkan pelanggaran dalam sistem akuntansi dengan pengetahuan dan keahliannya. Tandiontong (2015:240) juga menyatakan, kualitas adalah tingkat atau derajat baik buruknya mutu sesuatu. Kualitas reviu Laporan Keuangan Pemerintah Daerah tidak bisa langsung diamati, dan dinilai karateristiknya. Berdasarkan definisi-definisi tersebut, dapat disimpulkan bahwa kualitas memiliki ciri-ciri sebagai berikut:

a. Sesuatu dianggap berkualitas jika sesuai dengan persyaratan-persyaratan tertentu;

b. Fitur dan karateristik produk atau jasa dapat memenuhi harapan pelanggan baik dari aspek marketing, engineering, produksi dan pemeliharaan. 


\section{Metode Penelitian}

Jenis penelitian ini adalah penelitian kuantitatif yaitu saintifik menggunakan struktur teori untuk membentuk hipotesa dan kemudian menggunakan fakta atau data empiris untuk menguji hipotesis mendapatkan kesimpulan. Tujuan penelitian ini untuk menguji secara empiris mengenai pengaruh prosedur reviu, kompetensi, jangka waktu pelaksanaan terhadap kualitas reviu Laporan Keuangan Pemerintah Daerah. Teknik analisis yang digunakan dalam penelitian ini adalah analisis regresi linier berganda. Populasi dalam penelitian ini adalah 313 aparat pengawas pada 7 (tujuh) Inspektorat yang ada di Provinsi Gorontalo. Sampel dalam penelitian ini adalah yang memenuhi kriteria aparat pengawas yang pernah melakukan reviu Laporan Keuangan Pemerintah Daerah sebanyak 92 responden yang tersebar di 7 (tujuh) Inspektorat se-Provinsi Gorontalo. Pengambilan sampel dari populasi pada penelitian ini dilakukan dengan teknik purposive sampling.

\section{Hasil dan Pembahasan}

Pengujian dilakukan menggunakan analisis faktor konfirmatori (confirmatory factor analysis). Sementara itu, uji reliabilitas digunakan untuk mengetahui tingkat reliabel atau kehandalan dalam bentuk konsistensi jawaban yang diberikan responden atas setiap pertanyaan yang ada di dalam kuisioner. Pengujian menggunakan uji statistik Cronbac's Alpha dengan batasan nilai $>0,6$ dinyatakan reliabel. Hasil uji validitas dengan menggunakan analisis faktor konfirmatori atas sejumlah item pertanyaan setiap variabel penelitian ini, yaitu prosedur reviu, kompetensi, jangka waktu pelaksanaan, dan kualitas reviu Laporan Keuangan Pemerintah Daerah. Hasil penelitian menunjukkan pada nilai Kaisar-Meyer-Olkin Measure of Sampling Adequacy (KMO MSA) dan hasil rotasi faktor dengan metode varimax. Hasil pengujian reliabilitas menggunakan teknik Cronbac's Alpha. Suatu instrumen dapat dikatakan reliabel bila memiliki koefisien keandalan atau Cronbach's Alpha $>0,60$. Hal ini dapat dilihat dari nilai Cronbach's Alpha masing-masing variabel adalah lebih besar dari 0,60. Prosedur reviu 0,844; kompetensi 0,800; jangka waktu pelaksanaan 0,737; dan kualitas reviu 0,855 .

Uji normalitas dilakukan untuk mengetahui data berdistribusi normal. Uji normalitas bertujuan untuk menguji apakah dalam model regresi variabel terikat dengan variabel bebas keduanya mempunyai distribusi normal atau tidak. Untuk mengetahui data berdistribusi secara normal dilakukan uji Kolmogorof-Smirnov (Uji K-S). Hasil uji normalitas menunjukkan bahwa koefisien Kolmogorov-Smirnov $Z$ sebesar 0.658 dengan signifikan 0.780 . Nilai signifikansi lebih besar dari alpha $(\alpha=0,05)$ maka dapat diinterpretasikan bahwa model uji telah memenuhi asumsi normalitas.

Pengujian multikolinieritas dilakukan untuk melihat apakah pada model regresi ditemukan adanya korelasi antara variabel independen. Cara mendeteksinya adalah dengan melihat nilai tolerance dan nilai variance Inflation Factor (VIF). Jika nilai tolerance $>0,1$ dan VIF $<10$ maka variabel independen terbebas dari persoalan multikolinieritas. Hasil uji multikolinieritas membuktikan bahwa semua nilai tolerance $>0,1$ dan nilai $\mathrm{VIF}<10$. Hal ini menunjukkan bahwa semua variabel independen terbebas dari multikolinieritas.

Pengujian heteroskedastisitas dalam penelitian ini dilakukan dengan uji statistic Glejser. Metode uji glejser yaitu mengetahui kesamaan varian masing-masing variabel independen terhadap variabel dependen. Kriteria pengujian adalah bila signifikansi $>0,05$ berarti tidak terdapat heteroskedastisitas namun bila signifikansi $<0,05$ berarti terdapat heteroskedastisitas. Hasil uji heteroskedastisitas yang menghasilkan nilai signifikansi masingmasing variabel lebih besar dari 0,05 yang berarti bahwa probabilitas signifikansi variabel prosedur reviu sebesar 0,459 , variabel kompetensi 0,963 dan variabel jangka waktu pelaksanaan 0,295. Semua variabel independen menunjukkan probabilitas signifikansi diatas 
tingkat kepercayaan 0,05. Dengan demikian dapat disimpulkan bahwa model regresi ini memenuhi asumsi heteroskedasitisitas.

Hasil pengujian asumsi klasik menunjukkan bahwa model regresi yang dipakai telah memenuhi asumsi klasik sehingga dapat dilanjutkan dengan analisis regresi berganda. Model regresi berganda dalam penelitian ini adalah untuk menguji pengaruh prosedur reviu $\left(X_{1}\right)$, kompetensi $\left(\mathrm{X}_{2}\right)$, jangka waktu pelaksanaan $\left(\mathrm{X}_{3}\right)$ terhadap kualitas reviu $(\mathrm{Y})$. Hasil pengujian hipotesis diperoleh persamaan persamaan regresi berganda:

$Y=+\beta 1 X 1+\beta 2 X 2+\beta 3 X 3+e$

$Y=0.192+0.154 X 1+0.300 X 2+0.291 X 3+e$

Persamaan regresi berganda di atas dapat dijelaskan sebagai berikut.

1. Nilai Konstanta $(\alpha)$ sebesar 0.192 menunjukkan kualitas reviu $(Y)$ mempunyai hubungan positif atau searah dengan prosedur reviu $\left(X_{1}\right)$, kompetensi $\left(X_{2}\right)$, dan jangka waktu pelaksanaan $\left(X_{3}\right)$. Hal ini menunjukkan bahwa apabila prosedur reviu $\left(X_{1}\right)$, kompetensi $\left(X_{2}\right)$, dan jangka waktu pelaksanaan $\left(X_{3}\right)$ maka kualitas reviu akan meningkat sebesar 0.192 satuan.

2. Model penelitian untuk variabel prosedur reviu memiliki nilai koefisien regresi sebesar 0.154 dan bernilai positif, menunjukkan bahwa prosedur reviu berpengaruh positif terhadap kualitas reviu, artinya setiap peningkatan prosedur reviu maka akan mengakibatkan peningkatan dalam kualitas reviu $(\mathrm{Y})$.

3. Variabel kompetensi memiliki nilai koefisien regresi sebesar 0,300 dan bernilai positif, menunjukkan bahwa kompetensi berpengaruh positif terhadap kualitas reviu, artinya setiap peningkatan kompetensi maka akan mengakibatkan peningkatan kualitas reviu (Y), dengan asumsi faktor lain konstan.

4. Variabel jangka waktu pelaksanaan memiliki nilai koefisien regresi sebesar 0,291 dan bernilai positif, menunjukkan bahwa jangka waktu pelaksanaan berpengaruh positif terhadap kualitas reviu, artinya setiap peningkatan (perbaikan) jangka waktu pelaksanaan maka akan mengakibatkan peningkatan kualitas reviu (Y), dengan asumsi faktor lain konstan.

Pengujian hipotesis dengan uji $\mathrm{F}$ dilakukan untuk menunjukkan apakah semua variabel independen yang digunakan dalam model regresi mempunyai pengaruh positif dan signifikan secara bersama-sama terhadap variabel dependen. Hasil uji $F$ menunjukkan bahwa nilai $F_{\text {tabel }}$ $=2,71$. Hasil pengolahan data menunjukkan bahwa $F_{\text {hitung }}=14.015$ sehingga $F_{\text {hitung }}=14.015>$ $\mathrm{F}_{\text {tabel }}=2,71$ maka $\mathrm{Ha}$ diterima dan $\mathrm{H}_{0}$ ditolak. Dilihat dari nilai signifikansi menunjukkan bahwa nilai signifikansi adalah $0,000<0,005$ sehingga $\mathrm{H}_{a}$ diterima dan $\mathrm{H}_{0}$ ditolak. Hasil pengujian ini menunjukkan bahwa seluruh variabel independen yaitu prosedur reviu, kompetensi, jangka waktu pelaksanaan secara bersama-sama berpengaruh positif dan signifikan terhadap variabel dependen yaitu kualitas reviu Laporan Keuangan Pemerintah Daerah.

Pengujian hipotesis secara parsial (uji t) dilakukan untuk mengetahui besarnya pengaruh masing-masing variabel independen secara individual terhadap variabel dependen. Untuk mengetahui ada tidaknya pengaruh masing-masing variabel independen terhadap variabel dependen, dapat dilakukan dengan membandingkan $p$ value pada kolom $t$ dengan tingkat signifikansi yang digunakan sebesar $5 \%$. Hasil uji t membuktikan bahwa nilai $t_{\text {hitung }}$ dari prosedur reviu adalah 1,694. Artinya $t_{\text {hitung }}=1,694<t_{\text {tabel }}=1,97410$ dengan signifikansi dari variabel prosedur reviu adalah sebesar 0,094 >0,05. Hal ini menunjukkan bahwa $\mathrm{H}_{\mathrm{a}} 1$ ditolak dan $\mathrm{H}_{\mathrm{o}} 1$ diterima, terbukti bahwa prosedur reviu tidak berpengaruh positif dan signifikan terhadap kualitas reviu Laporan Keuangan Pemerintah Daerah pada Inspektorat se-Provinsi Gorontalo. 
Hasil uji t membuktikan bahwa nilai $t_{\text {hitung }}$ dari variabel kompetensi adalah 3,359. Artinya $t_{\text {hitung }}=3,359>t_{\text {tabel }}=1,97410$ dengan signifikansi dari variabel kompetensi adalah sebesar $0,01<0,05$. Hal ini menunjukkan bahwa $\mathrm{H}_{2} 2$ diterima dan $\mathrm{H}_{0} 2$ ditolak, sehingga terbukti bahwa kompetensi berpengaruh positif dan signifikan terhadap kualitas reviu Laporan Keuangan Pemerintah Daerah pada Inspektorat se Provinsi Gorontalo.

Hasil uji $t$ membuktikan bahwa nilai $t_{\text {hitung }}$ dari variabel jangka waktu pelaksanaan adalah 3,111. Artinya $t_{\text {hitung }}=3,111>t_{\text {tabel }}=1,97410$ dengan signifikansi dari variabel jangka waktu pelaksanaan adalah sebesar $0,003<0,05$. Hal ini menunjukkan bahwa $\mathrm{H}_{\mathrm{a}} 3$ diterima dan $\mathrm{H}_{\mathrm{o}} 3$ ditolak, sehingga terbukti bahwa jangka waktu pelaksanaan berpengaruh positif dan signifikan terhadap kualitas reviu Laporan Keuangan Pemerintah Daerah pada Inspektorat se-Provinsi Gorontalo.

Uji koefisien korelasi digunakan untuk mengetahui hubungan antara dua atau lebih variabel independen $\left(X_{1}, X_{2}, X_{3}\right)$ terhadap variabel dependen $(Y)$ secara serentak. Koefisien ini menunjukkan seberapa besar hubungan yang terjadi antara variabel independen $\left(X_{1}, X_{2}, X_{3}\right.$ ) secara serentak terhadap variabel dependen (Y). Uji koefisien determinasi dalam regresi linear berganda digunakan untuk mengetahui presentase sumbangan pengaruh variabel independen $\left(\mathrm{X}_{1}, \mathrm{X}_{2}, \mathrm{X}_{3}\right)$ secara serentak terhadap variabel dependen $(\mathrm{Y})$. Koefisien ini menunjukkan seberapa besar presentasi variasi variabel independen yang digunakan dalam model mampu menjelaskan variasi variabel dependen. Nilai $R$ square atau koefisien determinasi digunakan untuk mengetahui kemampuan variabel bebas untuk berkontribusi terhadap variabel tetapnya. Nilai R square sebesar 0,323 menunjukkan bahwa variabel bebas yakni prosedur reviu, kompetensi dan jangka waktu pelaksanaan menjelaskan 32,3\% variabel kualitas reviu. Sisanya sebesar $67,7 \%$ dijelaskan dengan variabel lain yang tidak diteliti.

\section{Pengaruh prosedur reviu terhadap kualitas reviu Laporan Keuangan Pemerintah Daerah}

Hasil pengujian Hipotesis pertama $\left(\mathrm{H}_{1}\right)$ menunjukkan bahwa pada prosedur reviu $t_{\text {hitung }}$ $=1,694<t_{\text {tabel }}=1.97410$ dengan nilai koefisien regresi sebesar 0.154 . Signifikasi dari prosedur reviu adalah $0.94>0,05$. Hal ini menunjukkan prosedur reviu tidak berpengaruh secara positif dan signifikan terhadap kualitas reviu Laporan Keuangan Pemerintah Daerah. Artinya hipotesis penelitian yang telah terbukti bahwa pengaruh prosedur reviu terhadap kemampuan pemahaman akan prosedur reviu aparat pengawas yang melakukan reviu Laporan Keuangan Pemerintah Daerah belum maksimal. Ini menunjukkan pelaksanaan reviu Laporan Keuangan Pemerintah Daerah sudah dilaksanakan akan tetapi dalam melakukan koreksi Laporan Keuangan Pemerintah Daerah dan mengimplementasi standar akuntansi yang digunakan untuk menghasilkan kualitas reviu Laporan Keuangan Pemerintah Daerah belum sepenuhnya sesuai dengan prosedur reviu yang ada.

Hal ini didukung oleh teori penetapan tujuan oleh Locke (1968), yang menyatakan bahwa tujuan rinci/spesifik mengarah pada hasil yang lebih baik dibandingkan dengan tujuan yang bersifat umum, karena tujuan tersebut memberi kejelasan bagi individu berkaitan dengan apa yang seharusnya dikerjakan. Penetapan tujuan yang bersifat spesifik akan menyebabkan peningkatan prestasi. Artinya, dalam melaksanakan prosedur reviu harus menetapkan tujuan secara lebih spesifik untuk dapat lebih mengarahkan langkah-langkah yang harus dilakukan dalam melaksanakan reviu sehingga dapat menghasilkan kualitas reviu yang baik.

Temuan ini tidak sejalan dengan hasil penelitian Widyarini dan Ratnadi (2016) yang menyatakan bahwa prosedur reviu berpengaruh positif dan signifikan pada kualitas reviu Laporan Keuangan Pemerintah Daerah, dimana semakin jelas prosedur reviu menyebabkan semakin baik pula kualitas reviu Laporan Keuangan Pemerintah Daerah. Prosedur reviu harus 
diungkapkan secara jelas agar anggota tim reviu mengerti langkah-langkah yang harus dilakukan. Tanpa prosedur reviu yang baik maka hasil reviu belum dapat memberikan informasi yang lengkap bahwa Laporan Keuangan Pemerintah Daerah telah disusun berdasarkan SPI dan sesuai dengan SAP.

\section{Pengaruh Kompetensi terhadap Kualitas Reviu}

Hasil pengujian Hipotesis kedua $\left(\mathrm{H}_{2}\right)$ menunjukkan bahwa pada kompetensi $t_{\text {hitung }}=3,359<$ $t_{\text {tabel }}=1.97410$ dengan nilai koefisien regresi hanya sebesar 0.300 . Signifikansi dari kompetensi adalah $0.01<0.05$. Hal ini menunjukkan kompetensi berpengaruh positif dan signifikan terhadap kualitas reviu Laporan Keuangan Pemerintah Daerah.

Hasil penelitian ini sejalan dengan teori yang dikemukakan oleh Edison et al. (2016), yang menyatakan bahwa kompetensi adalah kemampuan individu untuk melaksanakan suatu pekerjaan dengan benar dan memiliki keunggulan yang didasarkan pada hal-hal yang menyangkut pengetahuan (knowledge), keahlian (skill), dan sikap (attiude). Artinya, dengan adanya kompetensi aparat pengawas yang berkualitas dapat meningkatkan kualitas reviu Laporan Keuangan Pemerintah Daerah.

Hasil penelitian ini juga sejalan dengan Peraturan Menteri Negara Pendayagunaan Aparatur Negara Nomor PER/05/M.PAN/03/2008 tentang Standar Audit APIP, dimana APIP diharuskan mempunyai kemampuan untuk merencanakan audit, mengembangkan teknik dan metedologi audit, mengidentifikasi kebutuhan profesional auditor, sesuai dengan proses bisnis instansi/lembaga yang dilayani sehingga kinerja audit yang baik dapat dicapai. Hasil penelitian ini juga didukung oleh penelitian Amirullah et al. (2010), yang menyatakan bahwa kompetensi berpengaruh positif dan signifikan terhadap kualitas reviu Laporan Keuangan Pemerintah Daerah. Agar tidak terjadi kesalahpahaman dan kesalahan dalam penyusunan laporan reviu sangat dibutuhkan personil reviu yang berkompeten yang memiliki keahlian dan pelatihan teknis yang cukup sebagai auditor dan memahami konsep dasar reviu serta memahami secara garis besar sifat transaksi entitas, sistem dan prosedur akuntansi, bentuk catatan akuntansi dan basis akuntansi yang digunakan dalam menyajikan laporan keuangan.

\section{Pengaruh Jangka Waktu Pelaksanaan Terhadap Kualitas Reviu Laporan Keuangan Pemerintah Daerah}

Hasil pengujian Hipotesis kedua $\left(\mathrm{H}_{3}\right)$ menunjukkan bahwa pada jangka waktu pelaksanaan $t_{\text {hitung }}=3,111<t_{\text {tabel }}=1.97410$ dengan nilai koefisien regresi hanya sebesar 0.300. Signifikansi dari jangka waktu pelaksanaan adalah $0.03<0.05$. Hal ini menunjukkan jangka waktu pelaksanaan berpengaruh positif dan signifikan terhadap kualitas reviu Laporan Keuangan Pemerintah Daerah. Adapun teori yang mendukung penelitian ini adalah menurut Tandiontong (2015:201), dimana menyatakan anggaran waktu (time budget) adalah lamanya waktu yang tersedia yang akan digunakan untuk mengalokasikan waktu yang dibutuhkan setiap tahap pelaksanaan program audit.

Hasil peneltian ini sejalan dengan teori yang dikemukakan oleh De Zoort and Lord (1997) dalam Tandiontong (2015:201), yang menyatakan bahwa ketika menghadapi time budget pressure, auditor akan memberikan respon dengan dua cara yaitu fungsional dan disfungsional. Respon fungsional adalah perilaku auditor untuk bekerja lebih baik dan menggunakan waktu sebaik-baiknya. Hasil penelitian ini juga sejalan dengan teori yang dikemukakan oleh Basuki (2006) dalam Widyarini (2016), menyatakan bahwa anggaran waktu merupakan hal yang sangat penting karena menyediakan dasar untuk memperkirakan biaya audit, pengalokasian staf ke dalam pekerjaan audit dan sebagai dasar untuk mengevaluasi kinerja auditor. 
Hasil penelitian ini tidak sejalan dengan penelitian yang dilakukan oleh Widyarini dan Ratnadi (2016), yang menyatakan bahwa tekanan waktu (time pressure) berpengaruh negatif terhadap kualitas reviu Laporan Keuangan Pemerintah Daerah. Hasil analisis menunjukkan bahwa tekanan waktu berpengaruh negatif pada kualitas reviu Laporan Keuangan Pemerintah daerah. Hasil penelitian ini menunjukkan jangka waktu pelaksanaan reviu Laporan Keuangan Pemerintah Daerah lebih khusus pada tekanan waktu (time pressure) batas waktu penugasan reviu (time deadline) dan anggaran waktu pelaksanaan reviu (time budget pressure). Semakin ketat anggaran waktu maka kualitas reviu tidak maksimal. Pelaksanaan reviu laporan keuangan pemerintah daerah harus sesuai dengan jadwal pelaksanaan yang ada dalam pedoman pelaksanaan reviu Laporan Keuangan Pemerintah Daerah yaitu Permendagri Nomor 4 Tahun 2008 dilaksanakan secara paralel dengan penyusunan Laporan Keuangan Pemerintah Daerah paling lambat 2 (dua) bulan setelah tahun anggaran berakhir. Hal ini menunjukkan bahwa batas waktu yang ditekan dengan batas akhir pemasukan Laporan Keuangan Pemerintah Daerah dan anggaran waktu akan berpengaruh terhadap kualitas reviu Laporan Keuangan Pemerintah Daerah. Semakin efektif jumlah dan anggaran waktu yang diberikan maka pelaksanaan reviu yang dilakukan oleh aparat pengawas di Inspektorat Daerah akan semakin maksimal sehingga kualitas reviu Laporan Keuangan Pemerintah daerah yang dihasilkan akan semakin baik pula.

\section{Kesimpulan dan Saran}

Penelitian ini bertujuan untuk menguji secara positif dan signifikan pengaruh prosedur reviu, kompetensi, jangka waktu pelaksanaan terhadap kualitas reviu Laporan Keuangan Pemerintah Daerah (LKPD) pada Inspektorat se-Propinsi Gorontalo. Hasil penelitian ini menyimpulkan bahwa:

1. Prosedur reviu secara parsial tidak berpengaruh positif dan signifikan terhadap kualitas reviu LKPD pada Inspektorat se-Provinsi Gorontalo, hal ini disebabkan kemampuan pemahaman akan prosedur reviu aparat pengawas yang melakukan reviu Laporan Keuangan Pemerintah Daerah belum maksimal. Pelaksanaan reviu Laporan Keuangan Pemerintah daerah sudah dilaksanakan akan tetapi dalam melakukan koreksi Laporan Keuangan Pemerintah Daerah dan mengimplementasi standar akuntansi yang digunakan belum sepenuhnya sesuai dengan prosedur reviu yang ada, ini berarti bahwa jika pemahaman aparat pengawas terhadap prosedur reviu Laporan Keuangan Pemerintah Daerah lebih maksimal maka kualitas reviu Laporan Keuangan Pemerintah Daerah lebih baik pula.

2. Kompetensi berpengaruh secara positif dan signifikan terhadap kualitas reviu Laporan Keuangan Pemerintah Daerah pada Inspektorat se-Provinsi Gorontalo, berarti semakin tinggi kompetensi sumber daya aparat pengawas yang ada di Inspektorat se-Provinsi Gorontalo maka kualitas reviu Laporan Keuangan Pemerintah Daerah akan semakin baik. Jangka Waktu Pelaksanaan berpengaruh secara positif dan signifikan terhadap kualitas reviu Laporan Keuangan Pemerintah Daerah pada Inspektorat se-Propinsi Gorontalo. Semakin efektif jumlah dan anggaran waktu yang diberikan maka pelaksanaan reviu yang dilakukan oleh aparat pengawas di Inspektorat Daerah akan semakin maksimal sehingga kualitas reviu Laporan Keuangan Pemerintah daerah yang dihasilkan akan semakin baik pula.

Adapun saran yang dapat diberikan berdasarkan hasil penelitian yang telah dilakukan adalah sebagai berikut :

1. Pemerintah Daerah khususnya instansi pengawasan yaitu Inspektorat Daerah se-Provinsi Gorontalo diharapkan memberikan kesempatan bagi aparat pengawas agar dapat 
mengikuti pelatihan substantif reviu Laporan Keuangan Pemerintah Daerah dan mengalokasikan anggaran pelatihan tersebut pada Program Kerja Pengawasan Tahunan (PKPT) setiap tahun.

2. Pemerintah Daerah diharapkan dapat lebih mengoptimalkan kompetensi Sumber Daya Manusia (SDM), melalui penerimaan pegawai khususnya di Inspektorat se-Provinsi Gorontalo lebih ke formasi S1 Akuntansi.

3. Dalam peningkatan kapabilitas Aparat Pengawasan Internal Pemerintah (APIP), perlu meningkatkan kualitas reviu Laporan Keuangan Pemerintah Daerah dengan membuat Standar Operasional Prosedur (SOP) reviu Laporan Keuangan Pemerintah Daerah sebagai acuan pembuatan Program Kerja Pengawasan Tahunan (PKPT) untuk kegiatan reviu Laporan Keuangan Pemerintah Daerah. Standar jangka waktu pelaksanaan reviu Laporan Keuangan Pemerintah Daerah sesuai dengan Standar Reviu Laporan Keuangan Pemerintah Daerah yaitu PMK Nomor 8/PMK-09/2015, sehingga level peningkatan kapabilitas APIP yang akan dicapai semakin meningkat.

4. Bagi akademis bisa memberikan kontribusi terhadap peneliti selanjutnya untuk menguji variabel lain yang bisa mempengaruhi kualitas reviu Laporan Keuangan Pemerintah Daerah yakni kecermatan profesional terhadap kualitas reviu Laporan Keuangan Pemerintah Daerah serta faktor yang mempengaruhi pelaksanaan reviu Laporan Keuangan Pemerintah Daerah dikaitkan dengan keterlambatan penyusunan Laporan Keuangan Pemerintah Daerah.

\section{Daftar Pustaka}

Amirullah, A., Darwanis, D \& Yahya., M. R. 2010. The influence of Auditor'S Competence and Organization, Commitment to The Implementation of Financial Statement Review In Aceh Inspectorate. Jurnal Telaah \& Riset Akuntansi, 3 (2),130_154.

Arens, A. A., Elder, J. R., \& Beasley, S. M. 2014. Auditing \& Jasa Assurance (ke limabelas Jilid I). Jakarta, Indonesia: Erlangga: 18.

Edison, E., Anwar, Y., Komariyah, I. 2016. Manajemen Sumber Daya Manusia, Strategi dan Perubahan Dalam Rangka Meningkatkan Kinerja Pegawai dan Organisasi. Bandung: Alfabeta.

Fahmi, I. 2016. Managemen Sumber Daya Manusia. Teori dan Aplikasi. Bandung: Alfabeta.

Halim, Abdul \& Totok Budisantoso. 2014. Dasar-dasar Prosedur Pengauditan Laporan Keuangan. Yogyakarta: UPP STIM YPKN.

Hery. 2016. Analisis Laporan Keuangan, Integrated And Prehensive Edition. Jakarta : PT Grasindo.

Kuntadi, C. 2009. Auditor dan Pengamat Kebijakan Publik. Tangerang. Seminar dan Diskusi Panel Reviu Laporan Pemerintah Pusat/Daerah.

Locke, E. A. 1968. Toward a Theory of Task Motivation and Incentives, Organizational Behavior and Human Performance. 3:157-189.

Nugraha, E. 2010. Reviu Laporan Keuangan Pemda melalui Auditor Sektor Publik ;The Great Aim of Education is Not Knowledge, But Action. Diakses melalui https:// evaputranugraha.wordpress.com/2010/03/17/reviu-laporan-keuangan-pemda

Pemerintah Republik Indonesia Undang-undang Nomor 13 Tahun 2003 tentang Ketenagakerjaan Bab I Pasal 10.

-Undang-undang Nomor 32 tahun 2004 tentang Pemerintah Daerah. Peraturan Pemerintah Nomor 71 Tahun 2010 tentang Sistem Akuntansi Pemerintah. Peraturan Menteri Dalam Negeri Nomor 4 Tahun 2008 tentang Pedoman Pelaksanaan Reviu Laporan Keuangan Pemerintah Daerah. 
Peraturan Menteri Negara Pendayagunaan Aparatur Negara No.Per/05/M.PAN/03/2008 tentang Standar Audit Aparat Pengawasan Intern Pemerintah.

Tandiontong, M. 2016. Kualitas Audit dan Pengukurannya. Bandung: Alfabeta

Widyarini, K.,\& Ratnadi, N. M. D. 2016. Pengaruh Prosedur, Pendidikan,Tekanan Waktu, Dan Anggaran Reviu Pada Kualitas Reviu Laporan Keuangan Pemerintah Daerah. E Journal Ekonomi dan Bisnis Ekonomi Udayana. 5(3). 